\title{
ДИНАМІКА АКТИВНОСТІ ПРОЦЕСІВ ЛІПІДНОЇ ПЕРОКСИДАЦІЇ У ТКАНИНАХ ТОНКОЇ КИШКИ ЗА УМОВ ІШЕМІЇ-РЕПЕРФУЗІЇ КІНЦІВКИ, ГОСТРОЇ КРОВОВТРАТИ ТА ЇХ КОРЕКЦІЯ
}

\begin{abstract}
Динаміка активності процесів ліпідної пероксидації у тканинах тонкої кишки за умов ішемії-реперфузії кінцівки, гострої крововтрати та їх корекція
\end{abstract}

\section{В. В. Стрельбицька, А. А. Гудима, К. А. Походун}

Тернопільський національний медичний університет імені І. Я. Горбачевського мОЗ України

Резюме. У структурі сучасного травматизму воєнного і мирного часу значно зросла частка вогнепальних уражень, які часто супроводжуються масивною зовнішньою крововтратою. Накладання за цих умов кровоспинного джгута вважається єдиним способом порятунку на полі бою. Гостра крововтрата та ішемія-реперфузія кінцівки стимулюють активізацію процесів пероксидного окиснення ліпідів (ПОЛ) у внутрішніх органах. Однак порушення вільнорадикальних процесів у стінці тонкої кишки за цих умов вивчені недостатньо.

Мета дослідження - з'ясувати динаміку активності процесів ПОЛ у тканинах тонкої кишки за умов ішемії-реперфузії кінцівки, гострої крововтрати та оцінити ефрективність карбацетаму в корекції виявлених порушень.

Матеріали і методи. Експерименти виконано на 108 нелінійних щурах-самцях масою 200-220 2. Усіх тварин поділили на п'ять груп: контрольну та чотири дослідних. Під тіопентал-натрієвим наркозом у першій дослідній групі моделювали ішемію-реперфузію кінцівки, у другій - гостру крововтрату, в третій - ці ушкодження поєднували. У четвертій дослідній групі тваринам із гострою крововтратою та ішемією-реперфуззією кінцівки внутрішньочеревно вводили карбацетам в дозі 5 мг на кілограм маси тварини. Через 1 i 2 год, а також через 1; 7 і 14 діб у гомогенаті тонкої кишки визначали вміст дієнових кон'югатів та реагентів до тіобарбітурової кислоти.

Результати. За умов ішемії-реперорузії кінцівки та гострої крововтрати посилюються процеси ліпідної пероксидації у стінці тонкої кишки з максимумом через 1 добу експерименту. За умов моделювання лише ішемії-реперсузії кінцівки вміст первинних і вторинних продуктів ПОЛ до 14 доби експерименту нормалізується, то під впливом крововтрати показник до 14 доби залишався суттєво більшим порівняно з контролем. Поєднання ішемії-реперфузії кінцівки та гострої крововтрати вже з 2 год експерименту супроводжу-
Dynamics of activity of lipid peroxidation processes in small intestine tissues under conditions of limb ischemia-reperfusion, acute blood loss and their correction

\section{V. Strelbytska, A. A. Hudyma, K. A. Pokhodun}

I. Horbachevsky Ternopil National Medical University e-mail: arsgudyma@gmail.com.

Summary. The share of gunshot wounds in the structure of modern war and peacetime injuries has significantly increased, which is often accompanied by massive external blood loss. Applying a tourniquet under these conditions is considered the only way to escape on the battlefield. Acute blood loss and ischemia-reperfusion of the limb stimulate the activation of lipid peroxidation (LPO) in the internal organs. However, violations of free radical processes in the wall of the small intestine under these conditions are insufficiently studied.

The aim of the study - to determine the dynamics of the activity of LPO processes in the tissues of the small intestine under conditions of ischemia-reperfusion of the limb, acute blood loss, and to evaluate the effectiveness of carbacetam in the correction of identified disorders.

Materials and Methods. The experiments were performed on 108 nonlinear male rats weighing 200-220 g. All animals were divided into five groups: control and four experimental. Under thiopental-sodium anesthesia in the first experimental group was simulated ischemia-reperfusion of the limb, in the second - acute blood loss, in the third - these injuries were combined. In the fourth experimental group, animals with acute blood loss and ischemia-reperfusion of the limb were intraperitoneally administered carbacetam at a dose of $5 \mathrm{mg}$ per kilogram of animal weight. After 1 and 2 hours, as well as after 1, 7 and 14 days, the content of diene conjugates and thiobarbituric acid reagents in the small intestine homogenate was determined.

Results and Discussion. Under conditions of ischemiareperfusion of the limb and acute blood loss, the processes of lipid peroxidation in the wall of the small intestine are intensified with a maximum after 1 day of the experiment. Under the conditions of modeling only ischemia-reperfusion of the limb, the content of primary and secondary products of LPO up to 14 days of the experiment is normalized, then under the influence of blood loss, the figure up to 14 days remained significantly higher than the control. The combination of ischemia-reperfusion of the limb and acute 
ється більшим накопиченням продуктів ПОЛ, які до 14 доби статистично значуще перевищують інші дослідні групи. Карбацетам супроводжується позитивною антиоксидантною дією, який вже при семиденному застосуванні супроводжувався істотним зниженням вмісту первинних і вторинних продуктів ПОЛ у стінці тонкої кишки, що вказує на перспективність цього препарату за умов модельованої патології як засобу зниження проявів поліорганної диссрункції.

Висновки. Моделювання ішемії-реперфузії кінцівки на тлі гострої крововтрати супроводжується сумацією прооксидантного впливу обох патологічних втручань і викликає статистично вірогідно більше зростання вмісту ДК і ТБК-активних продуктів ПОЛ у стінці тонкої кишки, починаючи з 2 год експерименту. Застосування карбацетаму, порівняно з тваринами без корекції, вже через 7 діб реперфуззійного періоду викликає істотне зниження активності ПОЛ у стінці тонкої кишки.

Ключові слова: тонка кишка; крововтрата; ішемія-реперфузія кінцівки; ліпідна пероксидація; карбацетам.

\section{ВСТУП}

У структурі сучасного травматизму воєнного і мирного часу значно зросла частка вогнепальних уражень. 3 них у понад 60 \% випадків виникає ураження кінцівок, яке супроводжується масивною зовнішньою крововтратою. Своєчасність надання першої допомоги, зокрема накладання кровоспинного джгута, належить до основних методів рятування життя на полі бою $[1,2]$. Безпечний термін повної ішемії-реперфрузії кінцівки становить до двох годин.

Як свідчать результати досліджень окремих авторів, повне знекровлення кінцівки протягом цього терміну здатне викликати біохімічні та структурні порушення м'яких тканин як під джгутом, так і в зоні ішемії [3], які поглиблюються після реперфузії [4], і зумовлюють сукупність не тільки локальних, але й системних порушень. У їх механізмі лежить надходження в неуражені органи і тканини токсичних метаболітів з кінцівки, які здатні активізувати процеси ліпідної пероксидації у різних органах і тканинах, зокрема печінці [5, 6], нирці [7, 8], легенях [9]. Все це створює передумови для розвитку диссункції внутрішніх органів, яка поглиблюється при гострій крововтраті й неадекватній корекції може ускладнюватися поліорганною недостатністю та неспроможністю й зумовлювати загибель організму [10].

Однак активність процесів ліпідної пероксидації у тканинах тонкої кишки за умов ішемії-реперфузії кінцівки та гострої крововтрати вивчено недостатньо. Не досліджена за цих умов есективність карбацетаму, який, як свідчать дані ряду авторів, здатен знизити прояви ішемічно-репесрузійного синдрому та гострої крововтрати $[7,9,11]$. blood loss from 2 hours of the experiment is accompanied by a greater accumulation of LPO products, which up to 14 days are statistically significantly higher than other experimental groups. Carbacetam is accompanied by a positive antioxidant effect, which when used for seven days was accompanied by a significant reduction in the content of primary and secondary products of LPO in the small intestinal wall, which indicates the viability of this drug in simulated pathology as a means of reducing multiple dysfunction.

Conclusions. Simulation of limb ischemia-reperfusion on the background of acute blood loss is accompanied by the summation of the prooxidant effect of both pathological interventions and causes a statistically significant increase in the content of DC and TBA-active products of $\angle P O$ active products in the small intestinal wall starting from the second hour of experiment. The use of carbacetam compared to animals without correction after 7 days of the reperfusion period causes a significant decrease in the activity of the $P O L$ in the wall of the small intestine.

Key words: small intestine; blood loss; ischemiareperfusion of the limb; lipid peroxidation; carbacetam.

Метою дослідження було з'ясувати динаміку активності процесів ліпідної пероксидації у тканинах тонкої кишки за умов ішемії-реперсузії кінцівки, гострої крововтрати та оцінити ефективність карбацетаму в корекції виявлених порушень.

\section{МАТЕРІАЛИ I МЕТОДИ}

В експериментах використано 108 нелінійних щурів-самців масою 180-200 г, яких поділили на п'ять груп: контрольну та чотири дослідних (по 6 щурів у групі). Усі втручання виконані під тіопентал-натрієвим

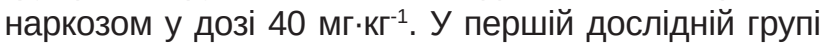
тваринам моделювали ішемію-реперсузію кінцівки. 3 цією метою на ліву лапку проксимально накладали смужку еластичного джгута «SWAT-T» (США) шириною 10 мм, який повністю припиняв кровотік протягом 120 хв. У другій дослідній групі шляхом пересікання стегнової вени моделювали гостру крововтрату (20 \% від об'єму циркулюючої крові). У третій дослідній групі ці ушкодження поєднували. В четвертій дослідній групі тваринам із гострою крововтратою та ішемією-реперфузією кінцівки, з корегувальною метою внутрішньочеревно вводили карбацетам (Інститут фрізико-органічної хімії і вуглехімії імені Л. М. Литвиненка НАН України, Київ) в дозі 5 мг на кілограм маси тварини [11]. У контрольній групі тварин тільки вводили в наркоз, застосовуючи еквівалентну дозу тіопенталу натрію.

Через 1 і 2 год, а також через 1; 7 і 14 діб в умовах тіопентал-натрієвого наркозу дослідних тварин виводили з експерименту методом тотального кровопускання з серця. В гомогенаті тонкої кишки визначали вміст реагентів до тіобарбітурової кислоти (ТБК-активних продуктів ПОЛ) [12] та дієнових кон'югатів (ДК) [13]. 
Під час роботи з лабораторними тваринами дотримувались міжнародних вимог про гуманне поводження 3 ними відповідно до правил Європейської конвенції про захист хребетних тварин, яких використовують 3 експериментальною та іншою науковою метою (Страсбург, 1986).

Оцінку вірогідності відмінностей між експериментальними групами проводили з використанням непараметричного критерію Манна - Уїтні.

\section{РЕЗУЛЬТАТИ Й ОБГОВОРЕННЯ}

Як видно з таблиці 1, внаслідок моделювання ішемії-реперсузії кінцівки вміст ДК у стінці тонкої кишки, порівняно з контролем, вже з 1 год експерименту зростав на 34,8 \% $(p<0,05)$, досягав максимуму через 1 добу експерименту (у 2,20 рази, p<0,05). В цей термін показник перевищував результат 1 год на 61,8 \% ( $<<0,05), 2$ год - на 25,5\% $(p<0,05)$. У подальшому показник знижувався й до 14 доби повертався до рівня контрольної групи ( $>0,05)$ та був статистично вірогідно меншим порівняно з результатом 2 год, 1 та 7 діб експерименту $(\mathrm{p}<0,05)$.

Після моделювання гострої крововтрати вміст ДК у стінці тонкої кишки через 1 год експерименту, порівняно з контролем, збільшувався на 64,3 \% ( $<<0,05)$, теж досягав максимальної величини через 1 год експерименту (у 3,44 раза, $p<0,05)$ й поступово знижувався до 14 доби. У цей термін показник ставав меншим від результату 2 год, 1 і 7 діб (відповідно на 23,6; 43,0 та 30,4 \%, p<0,05), проте залишався істотно більшим, ніж у контролі (на 96,4
$\%$, р<0,05). В усі терміни експерименту за умов моделювання гострої крововтрати вміст ДК у стінці тонкої кишки був статистично вірогідно більшим, ніж за умов моделювання лише ішемії-реперорузії кінцівки $\left(\mathrm{p}_{1-2}<0,05\right)$.

Ускладнення гострої крововтрати ішемією-реперфузією кінцівки супроводжувалося найбільшими порушеннями. Через 1 год експерименту вміст ДК у стінці тонкої кишки зріс на 85,7 \% ( $<<0,05)$, через 2 год - у 3,27 раза (p<0,05). Через 1 добу показник досягав максимуму, в 4,25 раза був більшим від контролю ( $<<0,05)$, істотно перевищував результат попередніх термінів спостереження $(p<0,05)$ й залишався на такому ж рівні до 7 доби експерименту ( $p<0,05)$. Через 14 діб вміст ДК у стінці тонкої кишки знижувався і ставав істотно меншим, порівняно 3 результатом 1 год, 1 і 7 діб експерименту (відповідно на 11,$5 ; 31,9$ та 30,8 \%, p<0,05), та залишався у $2,89$ раза більшим від контролю ( $<<0,05)$. За умов гострої крововтрати, ускладненої ішемією-реперфрузією кінцівки, вміст ДК у стінці тонкої кишки у всі терміни спостереження був статистично вірогідно більшим, ніж у групі, в якій моделювали лише ішемію-реперфузію кінцівки $\left(p_{1-3}<0,05\right)$, та, починаючи 32 год експерименту, порівняно 3 групою, в якій моделювали лише гостру крововтрату $\left(\mathrm{p}_{2-3}<0,05\right)$.

У свою чергу, вміст у стінці тонкої кишки ТБКактивних продуктів ПОЛ (табл. 2) після моделювання лише ішемії-реперфузії кінцівки, порівняно 3 контролем, теж зростав: через 1 год - на 17,5\%, через 2 год - на 25,3 \%, через 1 добу - на 42,9\%, через 7 діб - на 15,0 \%, що виявилося вірогідним

Таблиця 1. Динаміка вмісту дієнових кон'югатів (ум.од. 'мг-1) після гострої крововтрати, ускладненої ішемією-реперфрузією кінцівки ((Me (LQ;UQ) - медіана (нижній і верхній квартилі))

\begin{tabular}{|c|c|c|c|c|c|}
\hline \multirow{2}{*}{ Дослідна група } & \multicolumn{5}{|c|}{ Термін реперфузійного періоду } \\
\hline & 1 год & 2 год & 1 доба & 7 доба & 14 доба \\
\hline \multicolumn{6}{|c|}{ Контроль = 0,056 $(0,053 ; 0,058)(n=6)$} \\
\hline $\begin{array}{l}\text { Перша група } \\
\text { Ішемія-реперфузія }\end{array}$ & $\begin{array}{c}0,076^{*} \\
0,065 ; 0,081 \\
(n=6)\end{array}$ & $\begin{array}{c}0,098^{* 1 r} \\
0,086 ; 0,109 \\
(n=6)\end{array}$ & $\begin{array}{c}0,123^{\star 1 г, 2 г} \\
0,118 ; 0,130 \\
(n=6)\end{array}$ & $\begin{array}{c}0,081^{* 1 д} \\
0,078 ; 0,092 \\
(n=6)\end{array}$ & $\begin{array}{c}0,062^{2,1,1,7 \AA} \\
0,054 \\
0,067 \\
(n=6)\end{array}$ \\
\hline $\begin{array}{l}\text { Друга група } \\
\text { Крововтрата }\end{array}$ & $\begin{array}{c}0,092^{*} \\
0,087 ; 0,105 \\
(n=6)\end{array}$ & $\begin{array}{c}0,144^{* 1 r} \\
0,138 ; 0,150 \\
(n=6)\end{array}$ & $\begin{array}{c}0,193^{\star 1,2 r} \\
0,186 ; 0,206 \\
(n=6)\end{array}$ & $\begin{array}{c}0,158^{* 1 г, 1 д} \\
0,153 ; 0,166 \\
(n=6)\end{array}$ & $\begin{array}{c}0,110^{* 2 г, 1 д, 7 д} \\
0,098 ; 0,118 \\
(n=6)\end{array}$ \\
\hline $\begin{array}{l}\text { Третя група } \\
\text { Ішемія-реперфузія+ } \\
\text { крововтрата }\end{array}$ & $\begin{array}{c}0,104^{\star} \\
0,095 ; 0,106 \\
(n=6)\end{array}$ & $\begin{array}{c}0,183^{* 1 r} \\
0,167 ; 0,188 \\
(n=6)\end{array}$ & $\begin{array}{c}0,238^{\star 1,2 г} \\
0,233 ; 0,249 \\
(n=6)\end{array}$ & $\begin{array}{c}0,234^{* 1 \Gamma, 2 r} \\
0,229 ; 0,239 \\
(n=6)\end{array}$ & $\begin{array}{c}0,162^{* 1 г, 1 д, 7 д} \\
0,154 ; 0,175 \\
(n=6)\end{array}$ \\
\hline$p_{1-2}$ & $<0,05$ & $<0,05$ & $<0,05$ & $<0,05$ & $<0,05$ \\
\hline$p_{1-3}$ & $<0,05$ & $<0,05$ & $<0,05$ & $<0,05$ & $<0,05$ \\
\hline$p_{2-3}$ & $>0,05$ & $<0,05$ & $<0,05$ & $<0,05$ & $<0,05$ \\
\hline
\end{tabular}

Примітки. Тут і в табл. 2

1) * відмінності стосовно контролю статистично вірогідні $(p<0,05)$;

2) $p_{1-2}$ - вірогідність відмінностей між першою і другою дослідними групами;

3) $p_{1-3}$ - вірогідність відмінностей між першою і третьою дослідними групами;

4) $p_{2-3}$ - вірогідність відмінностей між другою і третьою дослідними групами. 
Таблиця 2. Динаміка вмісту ТБК-активний продуктів ПОЛ (мкмоль·кГ-1) після гострої крововтрати, ускладненої ішемією-реперсузією кінцівки ((Me (LQ;UQ) - медіана (нижній і верхній квартилі))

\begin{tabular}{|c|c|c|c|c|c|}
\hline \multirow{2}{*}{ Дослідна група } & \multicolumn{5}{|c|}{ Термін реперфузійного періоду } \\
\hline & 1 год & 2 год & 1 доба & 7 доба & 14 доба \\
\hline \multicolumn{6}{|c|}{ Контроль $=1,40(1,28 ; 1,44)(n=6)$} \\
\hline $\begin{array}{l}\text { Перша група } \\
\text { Ішемія-реперфузія }\end{array}$ & $\begin{array}{c}1,65^{*} \\
1,58 ; 1,71 \\
(n=6)\end{array}$ & $\begin{array}{c}1,75^{\star} \\
1,56 ; 1,91 \\
(n=6)\end{array}$ & $\begin{array}{c}2,00^{* 1 r} \\
1,82 ; 2,10 \\
(n=6)\end{array}$ & $\begin{array}{c}1,61^{* 1 д} \\
1,57 ; 1,66 \\
(n=6)\end{array}$ & $\begin{array}{c}1,34^{* 1,2 r, 1 A, 7 \AA} \\
1,30 ; 1,42 \\
(n=6)\end{array}$ \\
\hline $\begin{array}{l}\text { Друга група } \\
\text { Крововтрата }\end{array}$ & $\begin{array}{c}1,87^{*} \\
1,84 ; 1,89 \\
(n=6)\end{array}$ & $\begin{array}{c}2,13^{*} 1 \mathrm{r} \\
2,00 ; 2,20 \\
(\mathrm{n}=6)\end{array}$ & $\begin{array}{c}3,61^{* 11,2 r} \\
3,41 ; 3,73 \\
(n=6)\end{array}$ & $\begin{array}{c}3,23^{* 1,2 r} \\
3,14 ; 3,49 \\
(n=6)\end{array}$ & $\begin{array}{c}2,32^{* 1,2 \Gamma, 1 A, 7 \AA} \\
2,29 ; 2,42 \\
(n=6)\end{array}$ \\
\hline $\begin{array}{l}\text { Третя група } \\
\text { Ішемія-реперфузія+ } \\
\text { крововтрата }\end{array}$ & $\begin{array}{c}1,95^{\star} \\
1,83 ; 2,01 \\
(n=6)\end{array}$ & $\begin{array}{c}2,39^{* 1 r} \\
2,35 ; 2,50 \\
(n=6)\end{array}$ & $\begin{array}{c}4,44^{* 11,2 r} \\
3,96 ; 4,85 \\
(n=6)\end{array}$ & $\begin{array}{c}4,36^{\star 1,2 r} \\
4,25 ; 4,53 \\
(n=6)\end{array}$ & $\begin{array}{c}3,85^{* 1,2,2,7 \AA,} \\
3,78 ; 4,07 \\
(n=6)\end{array}$ \\
\hline$p_{1-2}$ & $<0,05$ & $<0,05$ & $<0,05$ & $<0,05$ & $<0,05$ \\
\hline$p_{1-3}$ & $<0,05$ & $<0,05$ & $<0,05$ & $<0,05$ & $<0,05$ \\
\hline$p_{2-3}$ & $>0,05$ & $<0,05$ & $<0,05$ & $<0,05$ & $<0,05$ \\
\hline
\end{tabular}

$(p<0,05)$. Через 14 діб показник досягав рівня контролю $(p>0,05)$ і ставав істотно меншим порівняно 3 усіма попередніми термінами спостереження $(p<0,05)$. За умов гострої крововтрати порушення були більш вираженими. Вже 31 год експерименту вміст ТБК-активних продуктів ПОЛ у стінці тонкої кишки зростав, порівняно 3 контролем, на 32,2 \% $(\mathrm{p}<0,05)$. Так само досягав максимуму через 1 добу (у 2,58 раза, p<0,05), залишався на такому ж рівні до 7 доби (p>0,05) й у подальшому до 14 доби знижувався порівняно 31 і 7 добами експерименту (відповідно на 35,8 та 28,2 \%, p<0,05). У цей термін показник був істотно більшим від контролю (на $65,7 \%, p<0,05)$ та порівняно з результатом 1 і 2 год експерименту $(p<0,05)$. В усі терміни спостереження гостра крововтрата зумовлювала статистично вірогідно більший вміст ТБК-активних продуктів ПОЛ у стінці тонкої кишки, порівняно $з$ дослідною групою, в якій моделювали лише ішемію-реперфузію кінцівки $\left(p_{1-2}<0,05\right)$.

Ускладнення гострої крововтрати ішемією-реперфузією кінцівки призводило до більшого накопичення ТБК-активних продуктів ПОЛ у стінці тонкої кишки. Вже через 1 год показник, порівняно з контролем, зріс на 39,9 \%, через 2 год - на 70,7 \% $(p<0,05)$. Проте вже через 1 добу величина дослідного показника збільшилася у 3,17 раза $(p<0,05)$ й залишалася на такому ж рівня до 7 доби експерименту ( $>>0,05)$. Через 14 діб показник знижувався, що було статистично вірогідним порівняно з результатом 7 доби експерименту (на 11,7 \%, р<0,05), проте продовжував залишатися суттєво більшим, ніж у контролі (у 2,75 раза, p<0,05) та 1 і 2 год експерименту (відповідно на 97,4 і 61,1 \%, р<0,05). В усі терміни експерименту величина дослідного показника в цій групі була статистично вірогідно біль- шою, ніж у групі, в якій моделювали лише ішеміюреперсрузію кінцівки $\left(p_{1-3}<0,05\right)$ та, починаючи 32 год експерименту, порівняно з групою, в якій моделювали лише гостру крововтрату $\left(p_{2-3}<0,05\right)$.

Застосування карбацетаму протягом 7 діб, порівняно зі щурами без корекції, сприяло статистично значущому зниженню вмісту ДК (рис. 1) у стінці тонкої кишки (на 21,4 \%, р<0,05), протягом 14 діб - на 26,5 \% ( $<<0,05)$, ТБК-активні продукти - відповідно на 21,3 та 33,2 \% (р<0,05) (рис. 2).

Отримані результати свідчать про те, що спільними механізмами ішемії-реперфузії кінцівки та гострої крововтрати є посилення процесів ліпідної пероксидації у стінці тонкої кишки з максимумом через 1 добу експерименту. Якщо за умов моделювання лише ішемії-реперфузії кінцівки вміст первинних і вторинних продуктів ПОЛ до 14 доби експерименту нормалізувалися, то під впливом крововтрати показник до 14 доби залишався суттєво більшим порівняно з контролем. Отже, порушення, зумовлені лише ішемією-реперфузією кінцівки знаходяться в межах гомеостатичного регулювання й адекватно забезпечені механізмами антиоксидантного захисту. Водночас, за умов гострої крововтрати під впливом патогенних чинників гемічної гіпоксії та зумовлених нею системних порушень до 14 доби експерименту активність ПОЛ залишається на достатньо високому рівні. Необхідно зауважити, що дану закономірність виявлено й стосовно печінки [11], нирок [7] та легень [9].

Поєднання ішемії-реперфузії кінцівки та гострої крововтрати вже з 2 год експерименту супроводжується більшим накопиченням продуктів ПОЛ, які до 14 доби статистично значуще перевищують інші дослідні групи. Можна припустити, що має місце ефрект сумації прооксидантного впливу як ішемії- 


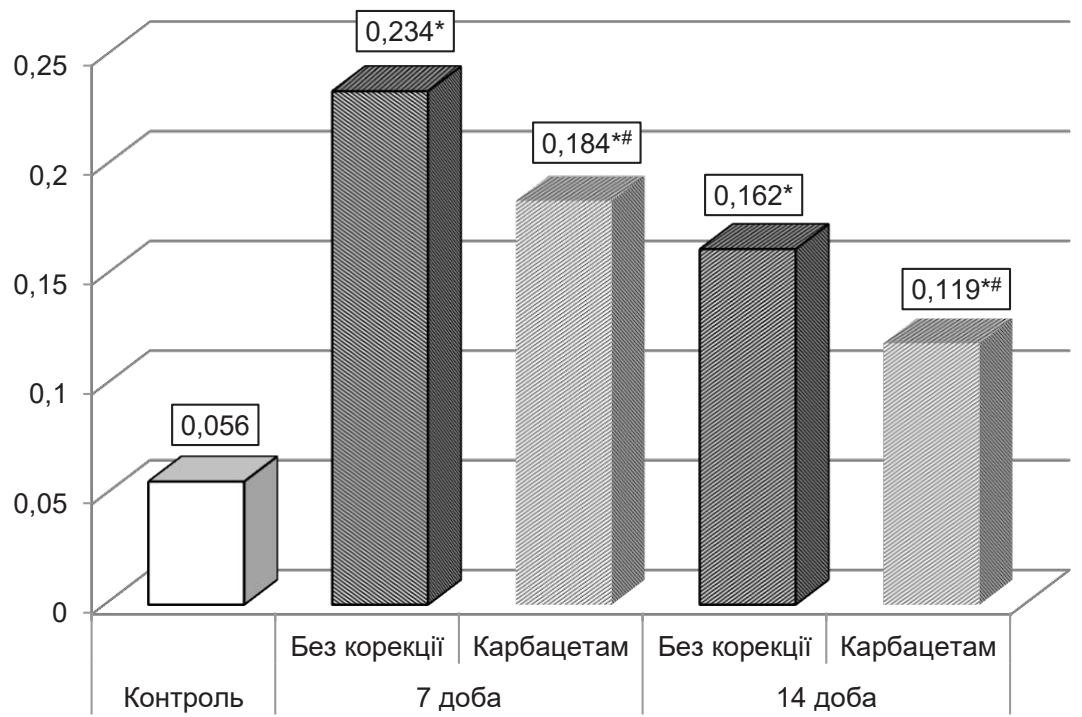

Рис 1. Вплив карбацетаму на вміст дієнових кон'югатів у стінці тонкої кишки (ум.од.·мгํㅡㄹ після гострої крововтрати, ускладненої ішемієюреперфузією кінцівки.

Примітки: 1) * - відмінності стосовно контролю статистично вірогідні, p<0,05;

2) \# - відмінності стосовно групи без корекції статистично вірогідні, p<0,05.

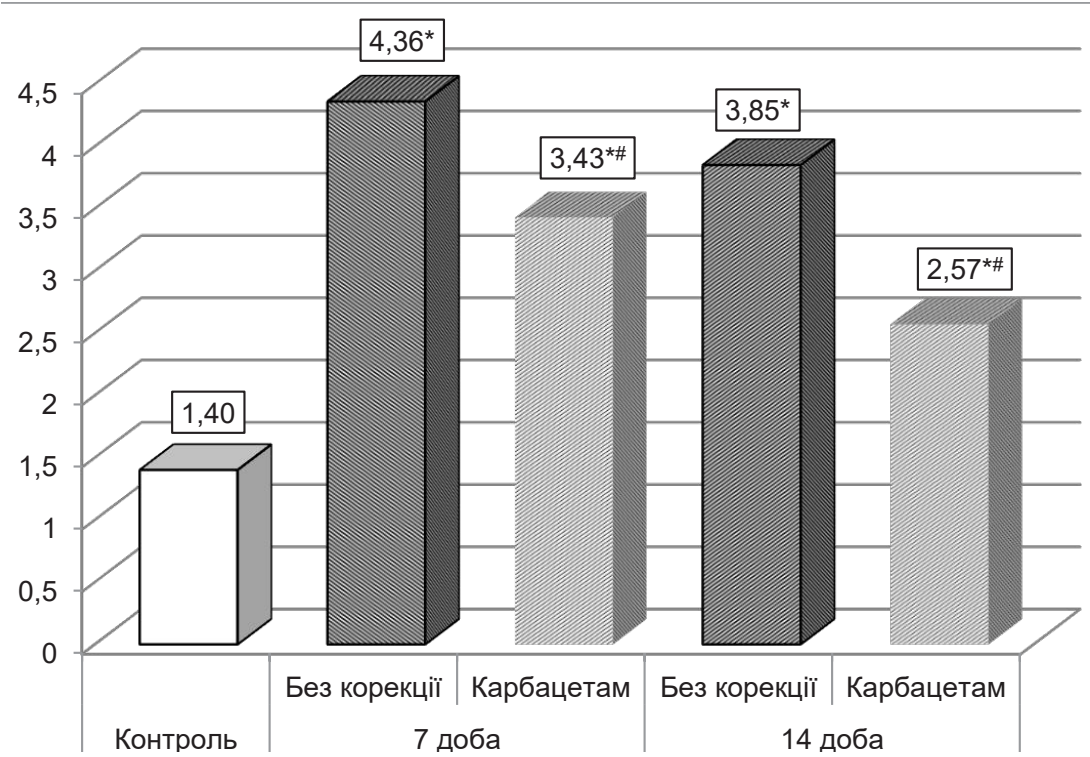

Рис. 2. Вплив карбацетаму на вміст МДА у стінці тонкої кишки (мкмоль кГ$^{-1}$ ) після гострої крововтрати, ускладненої ішемією-реперфрузією кінцівки.

реперфузії кінцівки, так і гострої крововтрати. Відомо, що інтенсифікація ПОЛ на тлі виснаження антиоксидантного захисту є пусковим чинником розвитку органної недостатності [10]. У зв'язку з цим, можна припустити, що активація ПОЛ у стінці тонкої кишки може тягнути за собою й розвиток ентеральної дисфрункції, що в експерименті встановлено за умов моделювання краніоскелетної травми [14].

Важливо відмітити позитивну антиоксидантну дію карбацетаму, який вже при семиденному застосуванні супроводжувався істотним зниженням вмісту первинних і вторинних продуктів ПОЛ у стінці тонкої кишки. Результати, які ми отримали, доповнюють дані інших авторів, що відмічали аналогічний вплив карбацетаму за умов ішемії-реперфузії кінцівки та гострої крововтрати на печінку, легені та нирки $[7,9,11]$. Виявлена, крім цього, окремими авторами мембраностабілізуюча і тканинопротекторна дія карбацетаму [15], вказує на перспективність цього препарату за умов модельованої патології як засобу зниження проявів поліорганної дисфункції. У перспективні доцільно дослідити 
вплив карбацетаму на фрункціональний стан тонкої кишки за умов ішемії-реперфузії кінцівки та гострої крововтрати.

\section{ВИСНОВКИ}

1. Унаслідок двогодинної ішемії та реперфузії кінцівки у стінці тонкої кишки посилюється активність ПОЛ, що виявляється зростанням вмісту ДК і ТБК-активних продуктів ПОЛ з максимумом через 1 добу реперфузійного періоду, яка до 14 доби досягає рівня контрольної групи.

2. За умов гострої крововтрати інтенсивність ПОЛ більша, порівняно 3 моделюванням лише ішемії-реперфузії кінцівки, теж досягає максимуму через 1 добу, проте до 14 доби не стихає i суттєво більша, ніж у контролі. Додаткове моделювання ішемії-реперфузії кінцівки на тлі гострої крововтрати супроводжується сумацією прооксидантного впливу обох патологічних втручань і викликає статистично вірогідно більше зростання вмісту ДК і ТБК-активних продуктів ПОЛ у стінці тонкої кишки, починаючи 32 год експерименту.

3. Застосування карбацетаму в тварин із гострою крововтратою, ускладненою ішемією-реперфрузією кінцівки, порівняно з тваринами без корекції, вже через 7 діб реперфузійного періоду викликає істотне зниження активності ПОЛ у стінці тонкої кишки, що вказує на виражену антиоксидантну дію препарату за умов модельованої патології.

\section{СПИСОК ЛІТЕРАТУРИ}

1. An evidence-based prehospital guideline for external hemorrhage control: American College of Surgeons Committee on Trauma / E. M. Bulger, D. Snyder, K. Schoelles [et al.] // Prehospital Emergency Care. - 2014. - No. 18. - P. 163-173.

2. Гайда І. М. Особливості структури та перебігу сучасної бойової травми у військовослужбовців Збройних Сил України / І. М. Гайда, М. І. Бадюк, Ю. І. Сушко // Pathologia. - 2018. - Vol. 15, № 1. - P. 73-76.

3. Телевяк А. Т. Динаміка показників перекисного окислення ліпідів та антиоксидантного захисту в м'язовій тканині задніх кінцівок щурів при розвитку ішемічно-реперфрузійного синдрому (експериментальне дослідження) / А. Т. Телевяк // Здобутки клініч. і експерим. медицини. 2018. - № 3 (35). - C. 132-139.

4. Clasper J. C. Limb complications following pre-hospital tourniquet use / J. C. Clasper, K. V. Brown, P. Hill // J. R. Army Med. Corps. - 2009. - Vol. 155 (3). - P. 200-202.

5. Максимів Р. Динаміка ліпідної пероксидації в печінці під впливом артеріального джгута і реперфузії кінцівки / Р. Максимів, І. Горбань, І. Стрельбицька // Матеріали XXII Міжнародного медичного конгресу студентів та молодих вчених (23-25 квітня 2018 р.). - Тернопіль : Укрмедкнига, 2018. - C. 266.

6. Кузьмінський І. В. Особливості жовчовидільної фуункції печінки в умовах ішемічно-реперфузійного синдрому кінцівок, закритої травми органів черевної порожнини, ускладненої масивною крововтратою / І. В. Кузьмінський // Актуальні проблеми транспортної медицини. - 2018. - № 4 (54). - С. 148-158.

7. Shatskyi V. V. Significance of lipid peroxidation processes in renal excretory dysfunction in cases of acute blood loss complicated by limb ischemia-reperfusion and its correction / V. V. Shatskyi, A. A. Hudyma // J. Educ. Health Sport. - 2019. - Vol. 9, No. 11. - P. 293-306.

8. Цимбалюк Г. Ю. Стан добового діурезу нирок в умовах ішемічно-реперфузійного синдрому кінцівок. Травми органів черевної порожнини, ускладненої гіповолемічним шоком, та їх поєднання у ранньому періоді травматичної хвороби / Г. Ю. Цимбалюк // Здобутки клініч. та експерим. медицини. - 2018. - Вип. 3 (35). - С. 163-169.

9. Стахів О. В. Вплив гострої крововтрати, ускладненої ішемією-реперфузією кінцівки, на активність процесів ліпідної пероксидації у легенях та їх корекція карбацетамом / О. В. Стахів, Р. В. Максимів // Вісник медичних і біологічних досліджень. - 2020. - № 3 (5). - С. 108-114.

10. Гудима А. А. Антиоксидантно-прооксидантний та цитокіновий баланс у пізній період комбінованої травми в експерименті / А. А. Гудима, Т. В. Кащак, К. В. Шепітько // Світ медицини та біології. - 2019. - № 1 (67). - С. 42-47.

11. Горбань І. І. Вплив гострої крововтрати, ускладненої ішемією-реперфузією кінцівки, на антиоксидантно-прооксидантний баланс печінки та його корекція карбацетамом / І. І. Горбань // Здобутки клініч. і експерим. медицини. - 2020. - № 2. - С. 93-100.

12. Доклінічні дослідження лікарських засобів: метод. рекомендації / за ред. О. В. Стефранова. - К. : Авіценна, 2001. - 528 с.

13. Методы изучения стрессовых и адаптационных реакций организма по показателям системы крови / А. В. Дерюгина, А. С. Корягин, С. В. Копылова, М. Н. Таламанова ; под редакцией В. Н. Крылова. - Нижний Новгород : Издательство Нижегородского госуниверситета, 2010. - 25 с.

14. Левчук Р. Д. Роль ліпопероксидації та антиоксидантного захисту в патогенезі ураження стінки тонкої кишки в динаміці краніоскелетної травми / Р. Д. Левчук, І. М. Дейкало // Здобутки клініч. і експерим. медицини. 2013. - № 2. - С. 120-123.

15. Козак Д. В. Вплив карбацетаму на антиоксидантний-прооксидантний баланс тканини серця, легень і печінки в динаміці політравми / Д. В. Козак // Шпитальна хірургія. - 2014. - № 1 (65). - С. 40-42. 


\section{REFERENCES}

1. Bulger EM, Snyder D, Schoelles K, Gotschall C, Dawson D, Lang E, et al. An evidence-based prehospital guideline for external hemorrhage control: American College of Surgeons Committee on Trauma. Prehosp. Emerg. Care. 2014;18: 163-173. Available from: DOI: $10.3109 / 10903127.2014 .896962$.

2. Gaida IM, Badyuk MI, Sushko Yul. [Peculiarities of structure and current of modern combat trauma among servicemen of the Armed Forces of Ukraine]. Pathologia. 2018;15(1): 73-76. Available from: DOI: 10.14739/2310-1237. 2018.1.129329. Ukrainian.

3. Televiak AT. [The dynamic of indicators of lipid peroxidation and antioxidant protection in muscle tissue of the hind limbs of the rats in development of the ischemicreperfusion syndrome (experimental study)]. Zdobutky klinichnoi i eksperymentalnoi medytsyny. 2018;3: 132-9. Available from: https://doi.org/10.11603/1811-2471.2018. v0.i3.9318. Ukrainian.

4. Clasper JC, Brown KV, Hill P. Limb complications following pre-hospital tourniquet use. J R Army Med Corps. 2009;155(3): 200-2. Available from: 10.1136/ jramc-155-03-06.

5. Maksymiv R, Gorban I, Strelbytska I. [Dynamics of lipid peroxidation in the liver under the influence of arterial tourniquet and limb reperfusion]. Proceedings of the XXII International Medical Congress of Students and Young Scientists (April 23-25, 2018). Ternopil: Ukrmedknyha; 2018. Ukrainian.

6. Kuzminskyi IV. [Peculiarities of biliary function of the liver in the conditions of ischemic-reperfusion syndrome of the extremities, closed trauma of the abdominal cavity, complicated by massive blood loss]. Aktualni problemy transportnoi medytsyny. 2018;4(54): 148-58. Ukrainian.

7. Shatskyi VV, Hudyma AA. Significance of lipid peroxidation processes in renal excretory dysfunction in cases of acute blood loss complicated by limb ischemiareperfusion and its correction. J Educ Health Sport. 2019;9;11: 293-306.

8. Tsymbalyuk HYu. [Daily urine renal state under ischemic-reperfusion syndrome of limbs, abdominal injury with hypovolemic shock and their combination in the early period of traumatic disease]. Zdobutky klinichnoi i eksperymentalnoi medytsyny. 2018;3(35): 163-9. Ukrainian.

9. Stakhiv OV, Maksymiv RV. [Influence of acute blood loss complicated by limb ischemia-reperfusion on the activity of lipid peroxidation processes in lungs and their correction with carbacetam]. Visnyk medychnykh i biolohichnykh doslidzhen. 2020;3(5): 108-14. DOI: 10.11603/bmbr.27066290.2020.3.11525. Ukrainian.

10. Hudyma AA, Kashchak TV, Shepitko KV. [Antioxidant-prooxidant and cytokine balance in the late period of combined trauma in the experiment]. Svit medytsyny ta biolohii. 2019;1(67): 42-7. Ukrainian.

11. Horban II. [The effect of acute blood loss complicated by limb ischemia-reperfusion on the antioxidant-prooxidant balance of the liver and its correction by carbacetam]. Zdobutky klinichnoi i eksperymentalnoi medytsyny. 2020;2: 93-100. Available from: DOI: https://doi.org/10.11603/18112471.2020.v.i2.11320. Ukrainian.

12. Stefanov OV. Ed. Preclinical studies of drugs: a method. recommendations. [Доклінічні дослідження лікарських засобів: метод. Рекомендації] Kyiv: Avitsenna; 2001. Ukrainian.

13. Deryugina AV, Koryagin AS, Kopylova SV, Talamanova MN. Methods of studying stress and adaptive reactions of the body by indicators of the blood system. [Методы изучения стрессовых и адаптационных реакций организма по показателям системы крови] Krylov VN. Ed. Nizhny Novgorod: Nizhny Novgorod State University Publishing House; 2010. Russian.

14. Levchuk RD, Deikalo IM. The role of lipoperoxidation and antioxidant protection in the pathogenesis of small bowel wall lesions in the dynamics of cranioskeletal trauma. Clin Achiev Exp Med. 2013;2:120-3.

15. Kozak DV. [Effect of carbacetam on antioxidant and prooxidant balance of heart lungs and liver tissues in polytrauma dynamic]. Shpytalna khirurhiia. 2014;1(65): 40-2. Available from: DOI: https://doi.org/10.11603/16812778.2014.1.4362. Ukrainian. 